University of Nebraska - Lincoln

DigitalCommons@University of Nebraska - Lincoln

Faculty Publications from Nebraska Center for Research on Children, Youth, Families, and Schools
Children, Youth, Families \& Schools, Nebraska Center for Research on

2004

\title{
Behind the Mirror Intervention in Family Therapy
}

Scott A. Ketring

Auburn University

Paul R. Springer

University of Nebraska - Lincoln, pspringer3@unl.edu

Follow this and additional works at: https://digitalcommons.unl.edu/cyfsfacpub

Part of the Pre-Elementary, Early Childhood, Kindergarten Teacher Education Commons

Ketring, Scott A. and Springer, Paul R., "Behind the Mirror Intervention in Family Therapy" (2004). Faculty Publications from Nebraska Center for Research on Children, Youth, Families, and Schools. 3. https://digitalcommons.unl.edu/cyfsfacpub/3

This Article is brought to you for free and open access by the Children, Youth, Families \& Schools, Nebraska Center for Research on at DigitalCommons@University of Nebraska - Lincoln. It has been accepted for inclusion in Faculty Publications from Nebraska Center for Research on Children, Youth, Families, and Schools by an authorized administrator of DigitalCommons@University of Nebraska - Lincoln. 


\title{
INTERVENTION INTERCHANGE
}

\author{
Thorana S. Nelson, Editor
}

\section{Behind the Mirror Intervention in Family Therapy}

\author{
Scott A. Ketring \\ Paul Springer
}

Therapists often work with adolescents who are the centerpiece of the family attention because of anti-social behaviors that seem to be self-destructive. These parents often share stories of bow their child is "special" and different from others. The parents believe that the unique traits of the child are causing their alienation from peers. The therapist is often told that the child deeply desires peer acceptance and is acting negatively to garner this acceptance. The parents are usually focused on the betterment of the child and have specific examples of how the adolescent is ruining his or her life or causing himself or herself needless

Scott A. Ketring is Assistant Professor, Marriage and Family Therapy Program, School of Human Development and Family Studies, Aubum University, Glanton House, Aubum, AL 36849.

Paul Springer is a doctoral student in Marriage and Family Therapy at Texas Tech University (E-mail: paul.r.springer @ttu.edu).

Address conrespondence to: Scott A. Ketring, Department of Human Development and Family Studies, Auburn University, Auburn, AL 36849 (E-mail: Ketring@ auburn.edu).

Jourual of Family Psychotherapy, Vol. 15(4) 2004

http://www.haworthpress.com/web/JP

(e) 2004 by The Hlaworth Press, lac. All rights reserved.

Digital Object Identifier: 10.1300/J085v15n04_07 
pain. The parents see the child's potential but seem unable to help their child see his or her special qualities.

The parental "hand wringing" seems to provide continuous positive and negative attention, which seems to please the adolescent. In all their despair these parents often do not establish boundaries or intrude excessively on the adolescent's boundaries in an attempt to force change. The desire to nurture the adolescent and protect from pain appears to override the desire to provide consequences for negative behaviors. The parents often appear caring but blind.

Therapists often find these parents least able to maintain therapeutic directives to gain more parental influence and hierarchy. It is under these circumstances that the parents may benefit from a behind-the-mirror intervention. During this intervention the therapist introduces the family to the supervisor or team members. These parents are often interested in gathering more "advice" for the case. After reviewing case progress and digression the supervisor or team is in a position to request that the parents spend some time behind the mirror discussing the case progress while the therapist continues with the adolescent. The adolescent has never objected to having the parents sit behind the mirror during the session. We hypothesize that the adolescent is lulled into a sense of security because they are the focus of attention without consequence.

Behind the mirror the supervisor or team can then ask direct questions while observing the session. The behind the mirror discussion includes parental views of therapeutic progress and the parental definition of the problem. After the parents are more comfortable the supervisor or team can offer several hypotheses about the case, which focus on the benefits the adolescent receives from his or her behavior. The conversation often focuses on the manipulation of the parents by the adolescent. The hypotheses are often offered in a one-down position about wondering. After the parents respond to the hypothesis the supervisor or team can then offer examples of why each hypothesis is formed. It is essential to offer examples for each hypothesis, whether the parents react in an accepting or rejecting manner. It seems that the experience of watching their child in session and discussing areas in which the parents may be perpetuating the problem can be helpful in attempting to help facilitate alternate perspectives.

\section{CASE EXAMPLE}

One such family attended therapy at our training center, because their teenage daughter was having emotional and often violent outbursts. The 
parents complained that their daughter acted immature and helpless when she became overwhelmed. At the same time, the parents doted on the daughter's talents and lamented that her church and school peers were insensitive. The adolescent presented the theme of not being understood. Changes seemed to occur but the therapists could not eliminate the adolescent's self-defeating tendencies. The parents seemed. unable to gain perspective of their role in maintaining the outbursts and behavior problems.

The therapist was confident that the parents could play a key role in changing their daughter's emotional state and behavior problems. During a brainstorming period within supervision, it was suggested that moving the parents to the observation booth behind the two-way mirror during session would negate the ability to take care of their daughter. Additionally, the supervisor would visit with the parents during their observation of the session. The therapist spoke with the family about the possibility of the supervisor coming into the session and participating. The supervisor interrupted the session during a segment in which the adolescent was focusing on the "drama of her life." The supervisor requested that the parents might gain a different perspective watching from the other side of the mirror. The daughter was excited to have the session to herself and did not care if her parents observed.

The supervisor and parents sat behind the mirror and casually began talking while observing the session. The discussion included parental views of therapeutic progress, the differences in services between the current and former therapists, and parental definition of the problem. Then the supervisor offered the following perspective:

SUPERVISOR: "I am wondering if your daughter turns to you to save her when confronted with lack of responsibility or immature behavior."

PARENTS: "No, that doesn't sound right."

SUPERVISOR: "Really, are you sure, because .. . ?" 'The supervisor begins to offer specific examples which corroborate the hypothesis.

MOTHER: "I think she is willing to seek our advice and support." FATHER: "I also think she is the same type of person as myself." SUPERVISOR: "Yes, I heard this discussion on several occasions. To be honest with you, though. I thought she compared herself with you on mostly negative traits so that she could have a pass. It seems that when confronted on certain issues she points-out that one of you exemplifies these same negative characteristics." 
The discussion continued in an aniable manner. The parents enjoyed the conversation about therapy progress and seemed appreciative of the supervisor's observations. However, the parents mostly disagreed with the hypotheses of the supervisor. It was during this time that the supervisor took a one-down position, but pressed the issue until moving onto the next topic. These topics included concerns that the adolescent manipulated others to care for her; she pouted when things did not go her way and divided the parents on issues of discipline. The parents offered ideas of their daughter being a different type of adolescent, dealing with the emotions of being rejected by the peer group, and feeling lonely in a world full of adults. The supervisor listened and followed with additional observations. Following the session, the supervisor reported a mixed opinion concerning the behind-the-mirror intervention.

One week later the therapist sought out the supervisor and offered a surprising story. During the subsequent session the parents presented a united front on how they were going to deal with the problem. The therapist told of several occasions in which the parents intermupted the daughter and shared concerns that she was feeling sorry for herself and trying to get others to take care of her. Therapy became more fluid. The parents began implementing mles, boundaries, and began pushing their daughter. The daughter's behaviors shifted rapidly and within four sessions she completed therapy having eliminated angry outbursts, imesponsible behavior and improving academic success. The teachers had commented that she was acting more mature. Six-month follow-up also indicated continued progress without further digression.

\section{CONCLLSTON}

It is often difficult to help parents see their role in perpetuating indulgent and self centered adolescent behavior. The technique of offering the parents an altemative perspective from behind the mirror might be one way to create new parental dynamics. The added reinforcement from the supervisor seemed to strengthen the alliance with the parental subsystem, and increase the likelhood of collaborative and meaningful work.

\section{CONTRALDICATONS}

This type of therapeutic activity seemed warranted with an adolescent who demonstrated self-centered tendencies, often bordering on narcissism. However, it would seem that issues, that inherenty elicit 
shame and guilt, or issues that require high levels of trust and security, would be contraindicated for this type of interventions. Complications such as prior abuse, or life experiences that elicit shame, such as eating disorders, would not be conducive to this type of intervention. Family secrets that form around issues of sexuality and substance abuse by parents and/or children would also be contraindicated with the behind-the-mirror intervention. 